\title{
Quem tem documentos sobre a ditadura? Uma análise da legislação e das iniciativas governamentais ${ }^{1}$
}

\section{Vitor Amorim de Angelo²}

\section{Resumo}

Partindo da campanha publicitária do Centro de Referência das Lutas Políticas no Brasil (1964-1985), nosso objetivo neste trabalho é discutir o posicionamento do governo federal em relação aos arquivos da ditadura militar. Para tanto, recuperamos o longo debate iniciado no mandato de FHC em torno da divulgação dos documentos sigilosos produzidos pela ditadura. A reconstrução desse debate e a análise crítica da campanha publicitária nos permitiu apontar os limites e as contradições da atuação do governo brasileiro nessa questão.

Palavras-chave: Ditadura. Documentos. Campanha publicitária.

\section{Introdução}

Jo final de 2009, as principais emissoras de rádio e televisão do país, além de jornais e revistas de grande circulação, começaram a divulgar a campanha publicitária do Centro de Referência das Lutas Políticas no Brasil (1964-1985), também conhecido como

1 Uma versão preliminar deste trabalho foi apresentada no $7^{\circ}$ Encontro da Associação Brasileira de Ciência Política, realizado em Recife (PE) entre 4 e 7 de agosto de 2010. Agradeço às considerações feitas naquela oportunidade pelo debatedor da sessão, professor Dr. Luiz Cláudio Lourenço. Agradeço também aos pareceristas anônimos de Politica \& Sociedade pelas sugestões.

2 Doutor em Ciências Sociais pela Universidade Federal de São Carlos. Professor do Programa de Pós-Graduação em Ciências Sociais/Mestrado da Universidade Vila Velha (ES). E-mail: vitor.angelo@uvv.br 


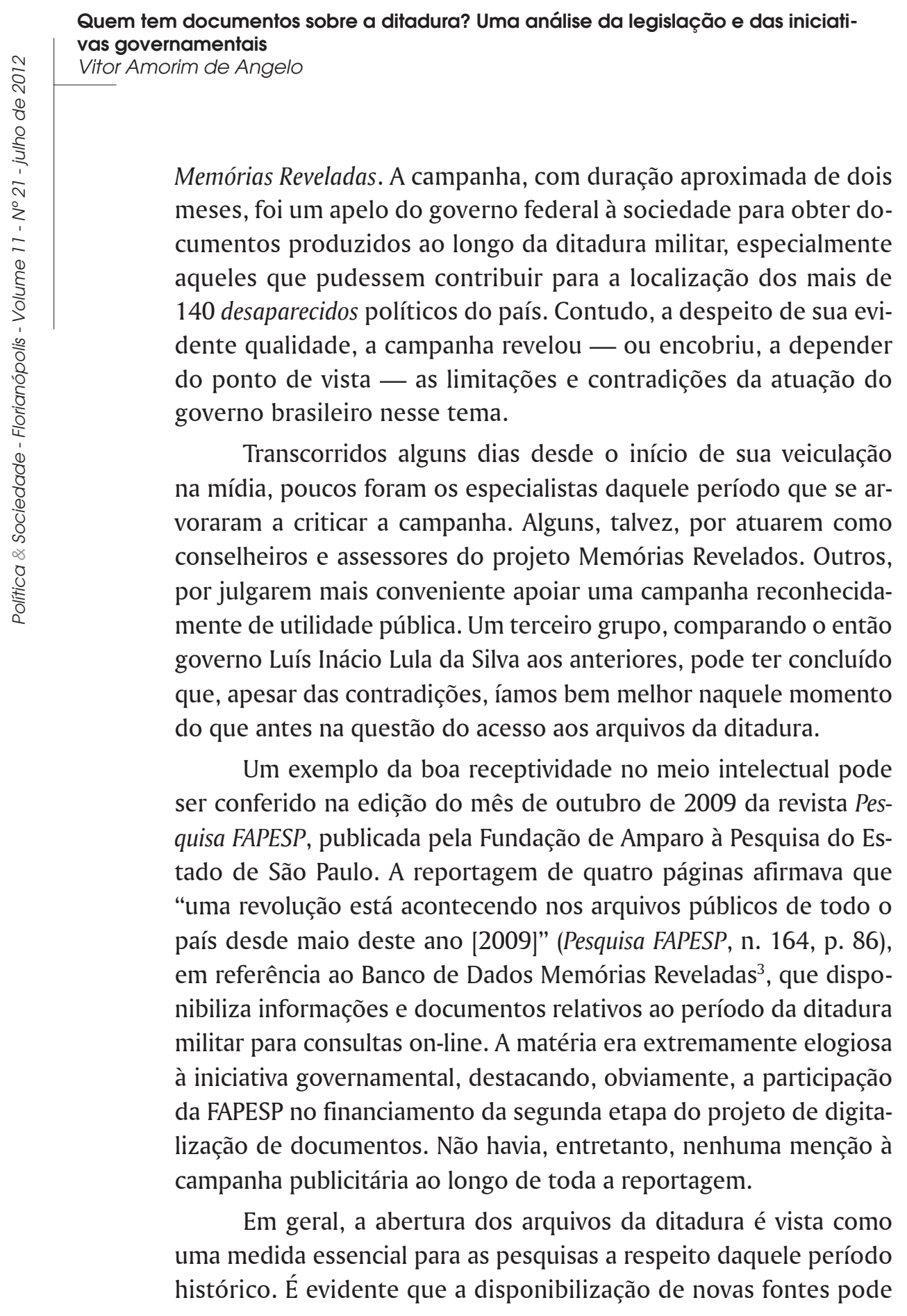

3 O banco de dados está disponível em: <www.an.gov.br/mr > . Acesso em: 1o ago. 2010. 
redirecionar a produção acadêmica, invalidar teses aparentemente sólidas e contribuir para uma reconstrução mais completa dos anos de chumbo. Faz parte, sobretudo, do direito à memória, seja dos atingidos pela repressão ou da sociedade como um todo ${ }^{4}$. Por outro lado, nota-se certo clima de euforia entre alguns pesquisadores, como se as fontes, por si só, pudessem dizer coisas novas. Esquecem que um corpo documental mais amplo não garante automaticamente pesquisas de maior qualidade a não ser que as perguntas corretas sejam feitas aos documentos ${ }^{5}$. Além do mais, não obstante o ethos racionalizante que caracterizou a repressão durante a ditadura, o que poderia favorecer a descoberta de novas informações, é presumível que não sejam encontradas revelações estarrecedoras como, às vezes, alguns setores da sociedade parecem crer $^{6}$.

Há também um componente pessoal na questão dos arquivos da ditadura. Muitas famílias buscam informações que possam levá-las a encontrar seus parentes desaparecidos durante o período militar. Esse foi o sentido mais evidente da campanha do Memórias Reveladas, que veiculou slogans como "ainda existem mais de 140 desaparecidos políticos no Brasil; ajude a encontrá-los" e "seus familiares ainda não tiveram o direito de enterrar seus corpos" ${ }^{\prime}$. A própria idéia de que alguém possa simplesmente desaparecer, aliás, é típica dos anos de extrema repressão que marcaram os sucessivos governos militares. Para fugir das forças de segurança, militantes da esquerda armada frequentemente entraram na clandestinidade

4 Na França, o direito à memória tem sido frequentemente associado ao chamado dever de memória (devoir de mémoire), com repercussão, inclusive, na esfera judicial. Uma análise esclarecedora sobre a relação entre história, memória e direito naquele país e um contraponto com o caso brasileiro podem ser vistos em Heymann (2007).

5 Para a visão de um conhecido historiador sobre a relação entre o pesquisador e suas fontes, ver Bloch (2001).

6 Com isso, porém, não queremos afirmar que: (1) não haja documentos a serem revelados, que (2) documentos com informações tidas como bombásticas não poderiam surgir nem tampouco que (3) existam documentos mais importantes do que outros em razão desta ou daquela informação neles contida.

7 As informações relativas à campanha utilizadas ao longo do texto estão disponíveis no site oficial do Memórias Reveladas: <www.memoriasreveladas.arquivonacional.gov.br >. Acesso em: $1^{\text {o }}$ ago. 2010. 


\section{Quem tem documentos sobre a ditadura? Uma análise da legislação e das iniciati- vas governamentais \\ Vitor Amorim de Angelo}

para nunca mais sair. Naquele verdadeiro "combate nas trevas" (GORENDER, 1987), os guerrilheiros se tornaram vítimas relativamente fáceis para seus algozes ${ }^{8}$.

Embora constituam maioria entre os desaparecidos políticos, os que pegaram em armas para derrubar a ditadura não são os únicos procurados. Durante o período militar, tornou-se comum agentes da repressão sem mandado judicial deterem suspeitos de praticar atividades subversivas ou de ter informações que pudessem levar à prisão de nomes procurados pela ditadura. Alguns, entretanto, jamais voltaram para casa, desaparecendo sem deixar vestígios, como é o caso do ex-deputado Rubens Paiva, morto em 1971 após sofrer sessões de tortura no $1^{\circ}$ Batalhão da Polícia do Exército, no Rio de Janeiro9. Em todos os casos, as versões sustentadas pelas forças de segurança para se eximir de alguma culpa passaram a ser tão inverossímeis que apenas corroboravam as suspeitas de que a ditadura fizera mais uma vítima.

Meu objetivo neste trabalho é discutir o posicionamento do governo brasileiro, nos últimos anos, em relação aos arquivos da ditadura a partir da análise crítica da campanha publicitária do Memórias Reveladas. Com esse propósito, recuperei o longo debate iniciado no governo Fernando Henrique Cardoso em torno da divulgação dos documentos sigilosos produzidos pela ditadura militar. A reconstrução desse percurso e a análise da campanha publicitária, como será visto na parte final do trabalho, permitiu-me fazer alguns apontamentos sobre os limites, as contradições e também os avanços da atuação do governo brasileiro nessa questão.

\section{Idas e vindas na abertura dos arquivos da ditadura}

O livre acesso aos arquivos da ditadura tornou-se fundamental para pesquisadores interessados em estudar o período militar

\footnotetext{
8 Um trabalho fundamental para compreender a dinâmica das organizações armadas é Ridenti (1993).

9 Para o relato do caso, ver Veja, ed. 939, 3 set. 1986.
} 
e familiares à procura de informações a respeito de parentes desaparecidos. Em todos os governos da Nova República, a abertura dos acervos sempre foi uma questão delicada, que frequentemente suscitou debates acalorados e acusações de todos os lados. Os militares afirmam categoricamente que os documentos produzidos pelo aparelho repressivo já não existem mais, acusando os que insistem no assunto de revanchismo. Pesquisadores e familiares de desaparecidos, por sua vez, sustentam que os acervos existem, sim, mas que são escondidos pelas Forças Armadas, seja nas mãos de particulares envolvidos com a repressão ou dentro das próprias instituições militares.

Até o governo Lula, o Brasil avançou timidamente nessa questão. Atos públicos e falas contundentes nunca se traduziram em medidas concretas. Durante o governo Fernando Henrique Cardoso, chegou-se a distribuir convites para a cerimônia de abertura dos arquivos. $\mathrm{O}$ evento, porém, jamais ocorreu. Por outro lado, foi no primeiro mandato de FHC que se instituiu a Comissão Especial sobre Mortos e Desaparecidos Políticos (CEMDP) a fim de "envidar esforços para a localização dos corpos de pessoas desaparecidas" e "emitir parecer sobre os requerimentos relativos à indenização" (Lei n. 9.140/1995) ${ }^{10}$. A liberação dos documentos oficiais, entretanto, continuou no mesmo ponto.

A vitória de Lula em 2002 renovou a esperança de que o país poderia avançar mais rápido nessa questão. $O$ fato de o novo presidente ter sido eleito pelo Partido dos Trabalhadores (PT), que desde a sua fundação, nos anos 1980, tinha entre os seus quadros nomes ligados à antiga esquerda armada, contribuiu para reforçar a impressão de que um novo capítulo na história da abertura dos

10 Para além da criação da CEMDP, a importância da lei n. 9.140 reside no fato de que, pela primeira vez, o governo brasileiro reconhecia o envolvimento de agentes públicos na morte de pessoas desaparecidas em decorrência de seu envolvimento ou acusação de participação em atividades políticas no período compreendido entre 2 de setembro de 1961 e 15 de agosto de 1979. Dessa forma, o governo brasileiro reconheceu como mortas 136 pessoas, cujos nomes tinham sido identificados num dossiê elaborado pela Comissão de Familiares de Mortos e Desaparecidos Políticos (Cf. BRASIL, 2007). No final do governo FHC, uma nova lei (n. 10.536/2002) estendeu aquele prazo para 5 de outubro de 1988. 


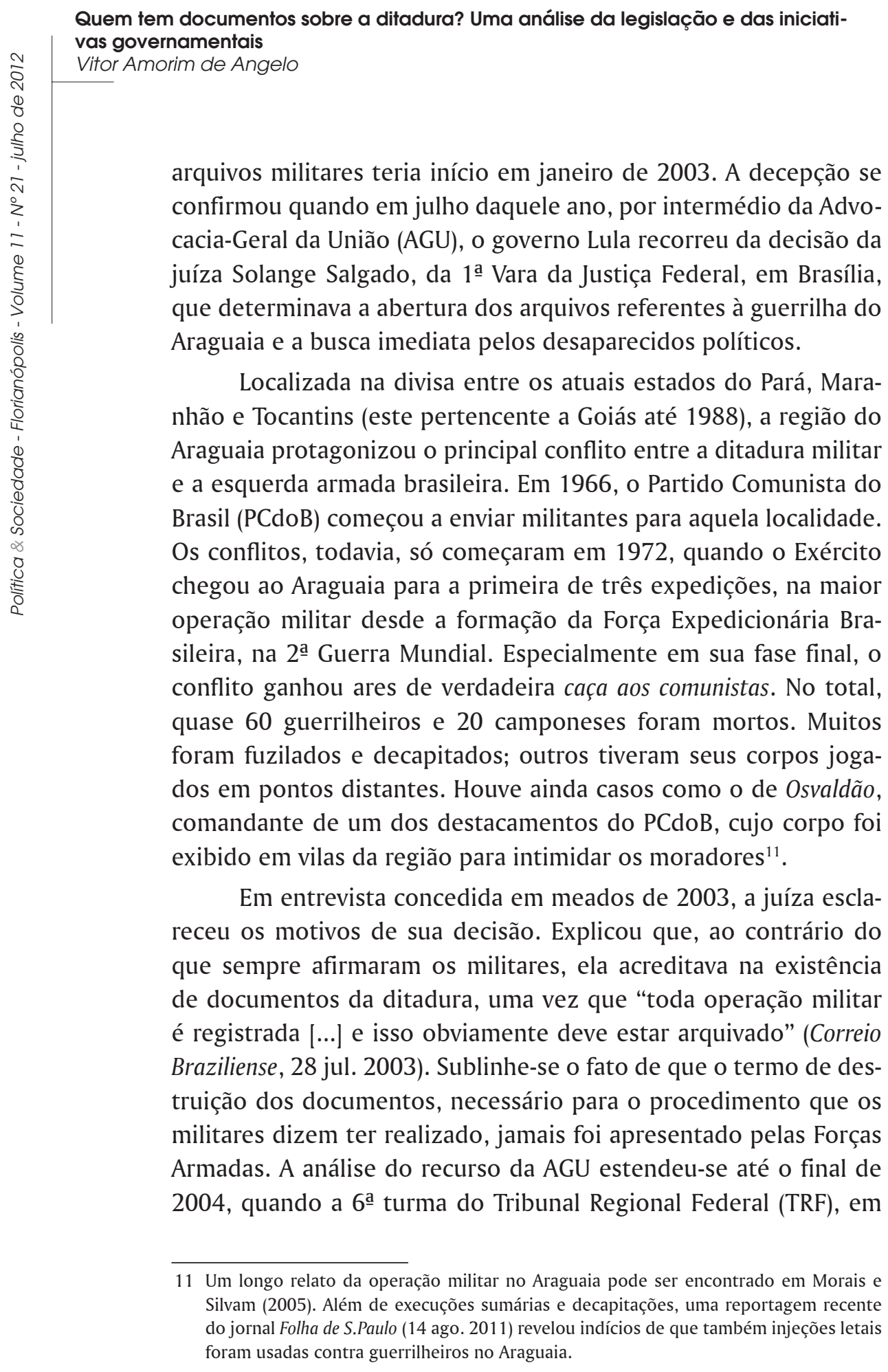


Brasília, confirmou por unanimidade a sentença dada em primeira instância.

Desgastado com o episódio, o Palácio do Planalto se viu obrigado a cumprir a decisão do TRF ${ }^{12}$. Apenas três dias depois, o presidente Lula assinou a medida provisória n. 228 e o decreto n. 5.301, regulamentando a divulgação de documentos públicos de interesse particular ou coletivo e instituindo a Comissão de Averiguação e Análise de Informações Sigilosas (CAAIS), colegiado subordinado à Casa Civil da Presidência da República ${ }^{13}$. Pelo prazo tão exíguo que separou os dois fatos, é possível que o texto da medida provisória e do decreto que a regulamentou não tenha sido preparado em decorrência da decisão do TRF, mas que estivesse na gaveta à espera da resposta ao recurso da AGU.

O debate interno que precedeu a decisão presidencial foi precipitado por uma polêmica envolvendo o Planalto, o ministério da Defesa e o Exército. Em 17 de outubro de 2004 (cerca de dois meses antes da sentença do TRF), o jornal Correio Braziliense divulgou em sua edição de domingo fotos que supostamente comprovariam os maus tratos sofridos por Vladimir Herzog nas dependências do II Exército, em São Paulo. Em 1975, ano de sua morte, Herzog era um jornalista de prestígio. Ex-professor da Universidade de São Paulo, tinha trabalhado para a BBC Brasil e possuía muitos contatos no exterior. Na época, era diretor da TV Cultura. Procurado pelos militares, compareceu voluntariamente ao quartel do II Exército em outubro daquele ano. Não sabia, porém, que era considerado um conspirador comunista.

No dia seguinte, o comando daquela unidade noticiou que o jornalista cometera suicídio em sua cela após assinar uma confissão declarando ser membro do Partido Comunista Brasileiro (PCB).

12 Ainda assim, o governo recorreu ao Superior Tribunal de Justiça (STJ), que confirmou, em junho de 2007, a sentença do TRF.

13 Em outubro do ano anterior, pouco depois da sentença da juíza Solange Salgado, o presidente assinou o decreto n. 4.850, criando uma comissão interministerial para responder à determinação da 1a Vara da Justiça Federal. A coordenação desse colegiado, ao contrário da CAAIS, coube ao ministério da Justiça. 


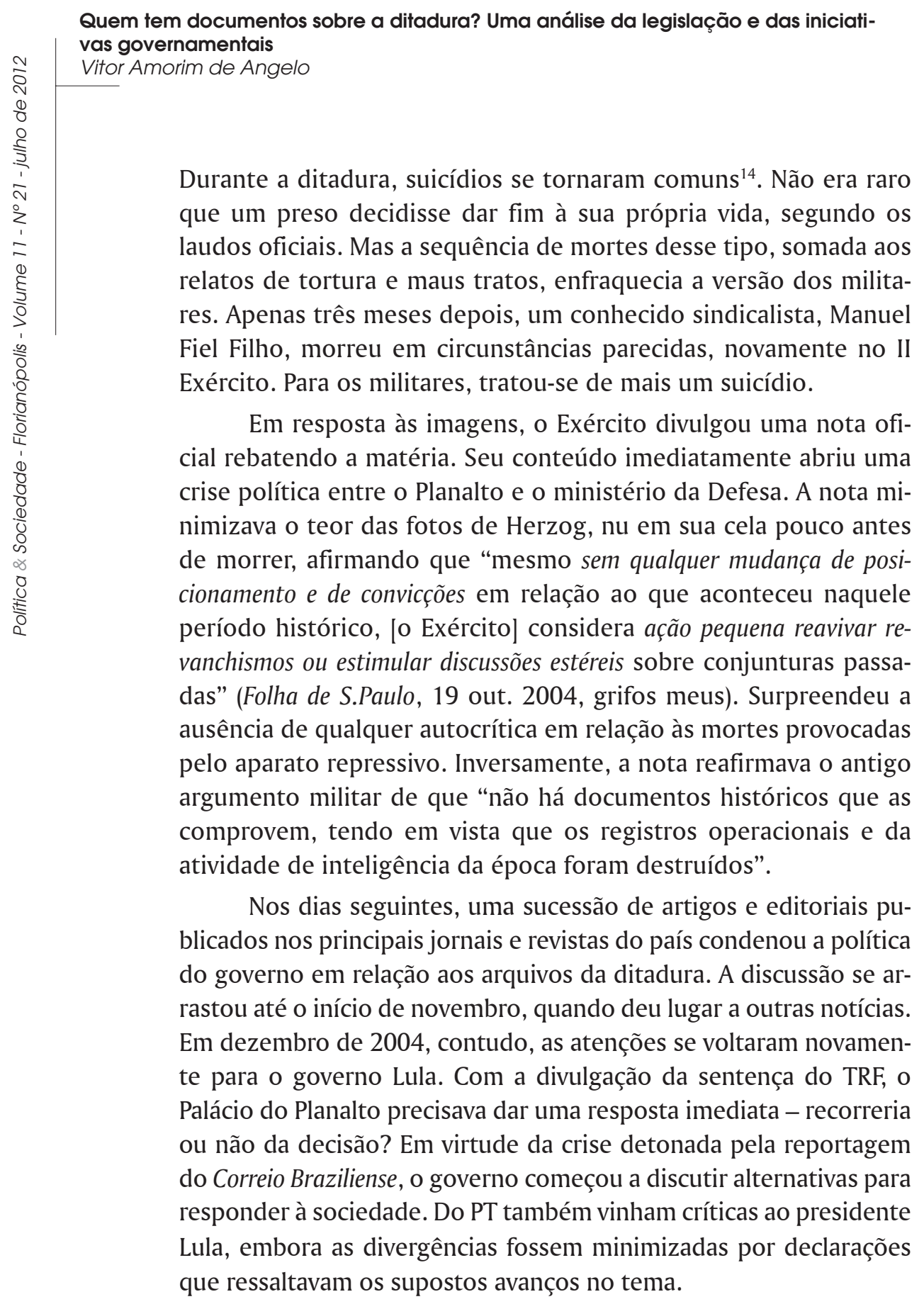

14 Até janeiro de 1976, oficialmente, foram 39, dos quais 19 por enforcamento (Cf. GASPARI, 2004). 
O fato é que o governo se dividiu com relação às medidas tomadas pelo presidente em no final de 2004. Parte apoiou a medida provisória e o decreto assinados por Lula, parte discordou enfaticamente do governo. Algumas evidências apontam nesse sentido. Um delas se refere à decisão do presidente em formar uma comissão interministerial responsável especificamente pela questão dos documentos, embora já existisse a Comissão Especial sobre Mortos e Desaparecidos Políticos. Em Direito à verdade e à memória, livro lançado em 2007 pela Secretaria Especial dos Direitos Humanos (SEDH), a divisão dentro do governo foi relembrada da seguinte maneira:

A tensão entre os dois colegiados foi visível, pois boa parte dos integrantes da CEMDP considerou a formação da Comissão Interministerial uma tentativa de esvaziar o trabalho por ela realizado. Em determinado momento, seus integrantes chegaram a cogitar a possibilidade de demissão coletiva (BRASIL, 2007, p. 43, grifos meus).

Aparentemente, a decisão de manter duas comissões poderia ser indício de que o governo tinha uma visão própria do assunto, separando a busca por mortos e desaparecidos políticos do acesso a informações sigilosas. Essa distinção tinha sido justamente o argumento utilizado pelo advogado-geral da União em 2003, no recurso à decisão da juíza Solange Salgado. Na época, a AGU alegou que, ao ordenar a abertura dos arquivos da ditadura, a juíza teria extrapolado o pedido dos autores da ação, que reclamavam apenas a localização dos corpos. Ao confirmarem a sentença dada em primeira instância, os juízes da $6^{\underline{a}}$ turma do TRF lembraram que o acesso aos documentos produzidos durante a ditadura militar era determinante para iniciar qualquer tentativa de busca aos restos mortais de ex- guerrilheiros (Folha de S.Paulo, 7 dez. 2004).

Outra evidência do racha no governo foram as constantes mudanças feitas pelo presidente da República no organograma do primeiro escalão desde a sua posse. A CEMDP, como já foi dito, foi criada no governo FHC, subordinada à Secretaria dos Direitos da Cidadania do ministério da Justiça. Em 1997, com o decreto n. 2193, o governo criou a Secretaria Nacional dos Direitos Humanos, órgão pertencente à estrutura do ministério da Justiça. O decreto 


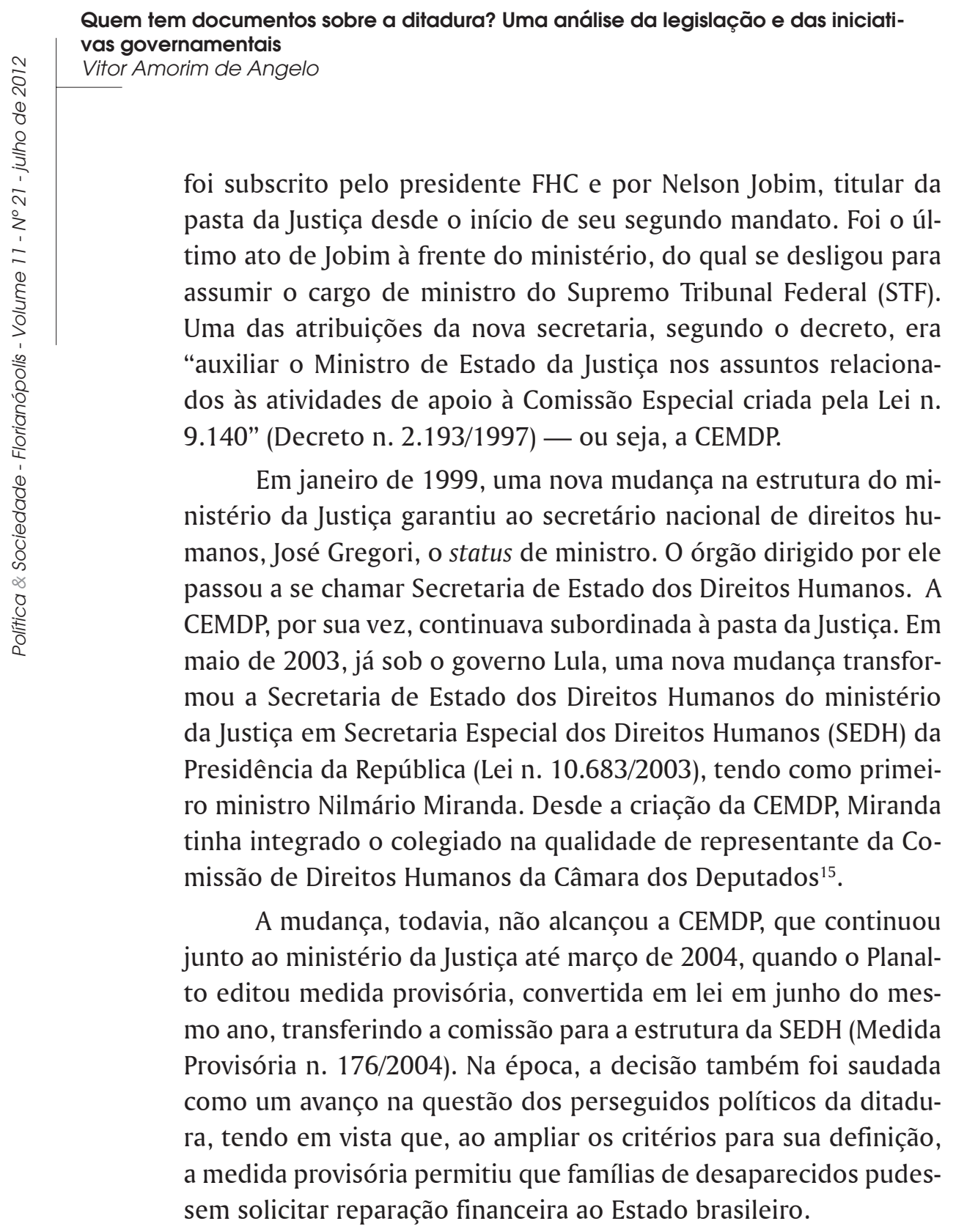

As constantes mudanças na estrutura do primeiro escalão não foram acompanhadas por ações concretas visando a abertura

15 A partir dos relatos feitos à CEMDP, Miranda publicou junto com Carlos Tibúrcio um grosso volume de mais de 600 páginas dedicado à questão da violação dos direitos humanos durante a ditadura militar. Ver Miranda e Tibúrcio (1999). 
dos arquivos. Até meados de 2004, o governo Lula nada tinha feito nesse sentido. Continuava valendo a medida draconiana assinada por FHC quatro dias antes de encerrar seu segundo mandato. Em 27 de dezembro de 2002, o governo Fernando Henrique havia editado medida provisória regulamentando o acesso a documentos públicos de conteúdo sigiloso. Pelas novas regras, os dados e informações manteriam a mesma classificação anterior, segundo o grau de sigilo: reservados, confidenciais, secretos ou ultrassecretos (Decreto n. 4.553/2002).

Além do presidente e do vice-presidente da República, teriam competência para realizar a classificação em todos os graus de sigilo ministros e comandantes das Forças Armadas. Autoridades que exercessem funções de direção, comando ou chefia poderiam atribuir apenas o grau de sigilo secreto. No caso de servidores civis e militares, sua competência se limitaria à classificação de documentos sigilosos como confidenciais ou reservados. Na prática, como destacou à época o jurista Alberto Nogueira Júnior, a medida significou que "em pleno regime democrático de direito, qualquer servidor, por menor que seja sua posição hierárquica no respectivo órgão ou entidade, poderá receber subdelegação para proceder àquelas classificações" (NOGUEIRA JÚNIOR, 2004).

O ponto mais polêmico do documento, porém, foram os prazos. Dados e informações reservados, confidenciais, secretos e ultrassecretos poderiam ser liberados para acesso apenas 10, 20, 30 e 50 anos após sua classificação, respectivamente. No caso dos documentos ultrassecretos, que incluíam boa parte do acervo da ditadura, o prazo para liberação, já aumentado em 20 anos na comparação com a lei anterior, poderia ser "renovado indefinidamente" em razão da "segurança da sociedade e do Estado"16. Para um presidente que tinha ido para o exílio fugindo da repressão, a medida mostrava enorme insensibilidade e falta de compromisso político com a causa dos direitos humanos.

16 A regulamentação anterior também tinha sido aprovada no governo FHC. De acordo com o decreto n. 2.134/1997, os documentos sigilosos, independentemente do grau de sigilo, poderiam ser classificados novamente apenas uma vez. Com as modificações introduzidas no final de 2002, criou-se a figura do sigilo eterno. 


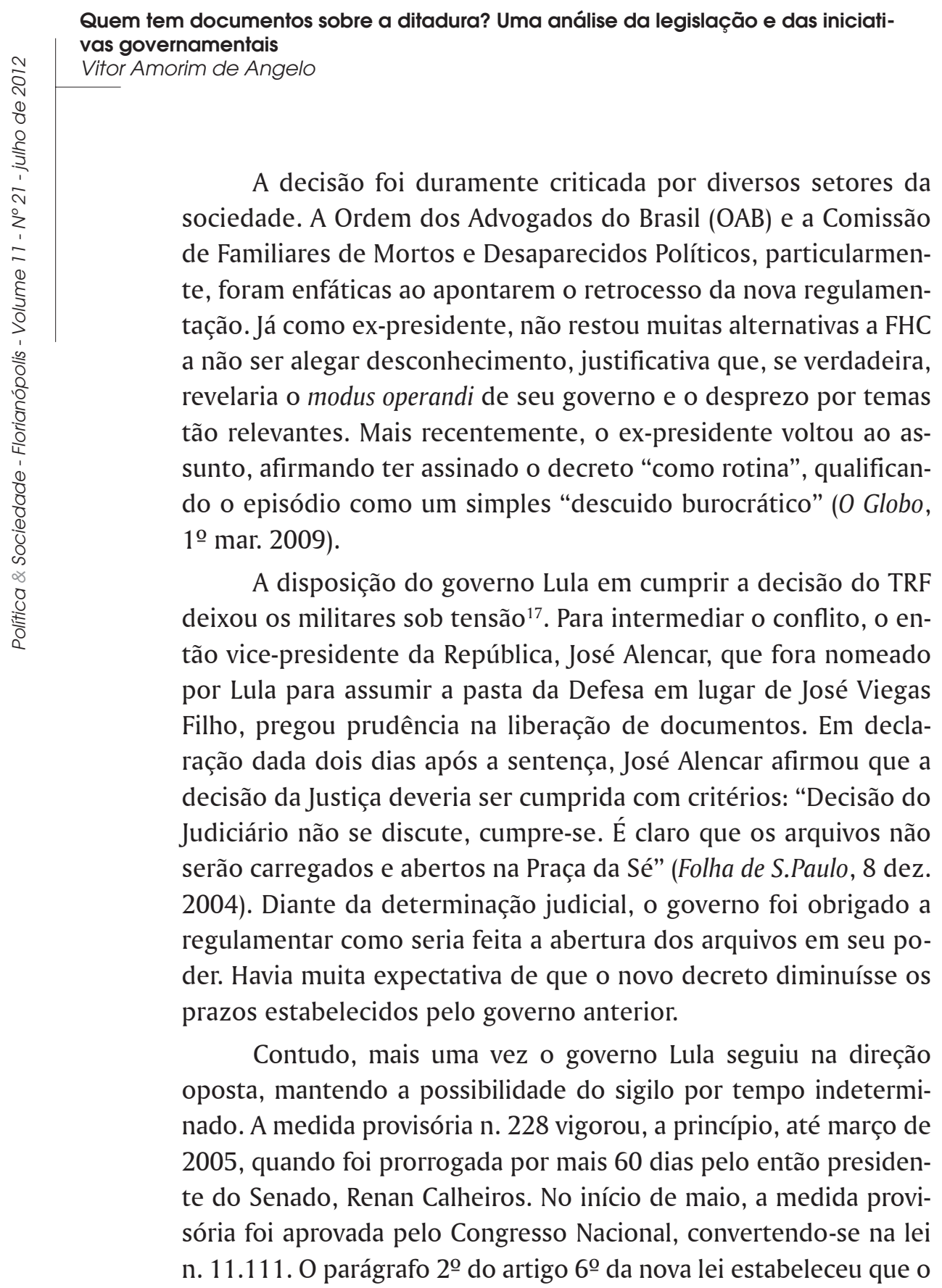

17 Foi revelador, nesse sentido, o relatório divulgado pela comissão interministerial criada por Lula em outubro de 2003. Segundo afirmou o documento, os militares impuseram como condição à sua ajuda o compromisso de que nenhuma informação fornecida ao colegiado seria usada em iniciativas de revisão da lei de anistia (Cf. Comissão, 2007). 
acesso aos dados e informações sigilosas seria permitido depois de encerrado o período de classificação dos documentos. Porém, antes de o prazo para a abertura dos arquivos expirar, seria possível, de acordo com as novas regras, postergar sua divulgação:

Antes de expirada a prorrogação do prazo de que trata o caput deste artigo, a autoridade competente para a classificação do documento no mais alto grau de sigilo poderá provocar, de modo justificado, a manifestação da Comissão de Averiguação e Análise de Informações Sigilosas para que avalie se o acesso ao documento ameaçará a soberania, a integridade territorial nacional ou as relações internacionais do País, caso em que a Comissão poderá manter a permanência da ressalva ao acesso do documento pelo tempo que estipular. (Lei n. 11.111/2005, grifos meus).

Em outras palavras, o governo reeditou a decisão amplamente criticada tomada por FHC no final de 2002. Um ponto a ser destacado na lei para as evidências que apontamos anteriormente é a composição do colegiado, cuja definição permaneceu a mesma do decreto n. 5.301. A CAAIS era integrada pelos ministros da Casa Civil, do Gabinete de Segurança Institucional, da Justiça, da Defesa e das Relações Exteriores, além do advogado-geral da União e do secretário especial dos direitos humanos. Comparada à CEMPD, era essencialmente política. Desde o início, esta comissão sempre contou com a participação de representantes das famílias dos desaparecidos, do Ministério Público Federal, da Comissão de Direitos Humanos da Câmara dos Deputados e da sociedade civil, de modo que suas decisões tendiam a refletir muito mais a preocupação com a memória dos desaparecidos do que um cálculo político visando equacionar as diferentes posições dentro do governo.

Em novembro de 2004, o jornal Folha de S.Paulo publicou uma longa entrevista com o então ministro-chefe do Gabinete de Segurança Institucional do governo Lula, general Jorge Armando Félix. Embora não falasse em nome das Forças Armadas, o general reproduziu o posicionamento dos militares a respeito do assunto, além de evidenciar a divisão dentro do Planalto. Ao jornal, o ministro declarou-se contrário à divulgação dos documentos, 


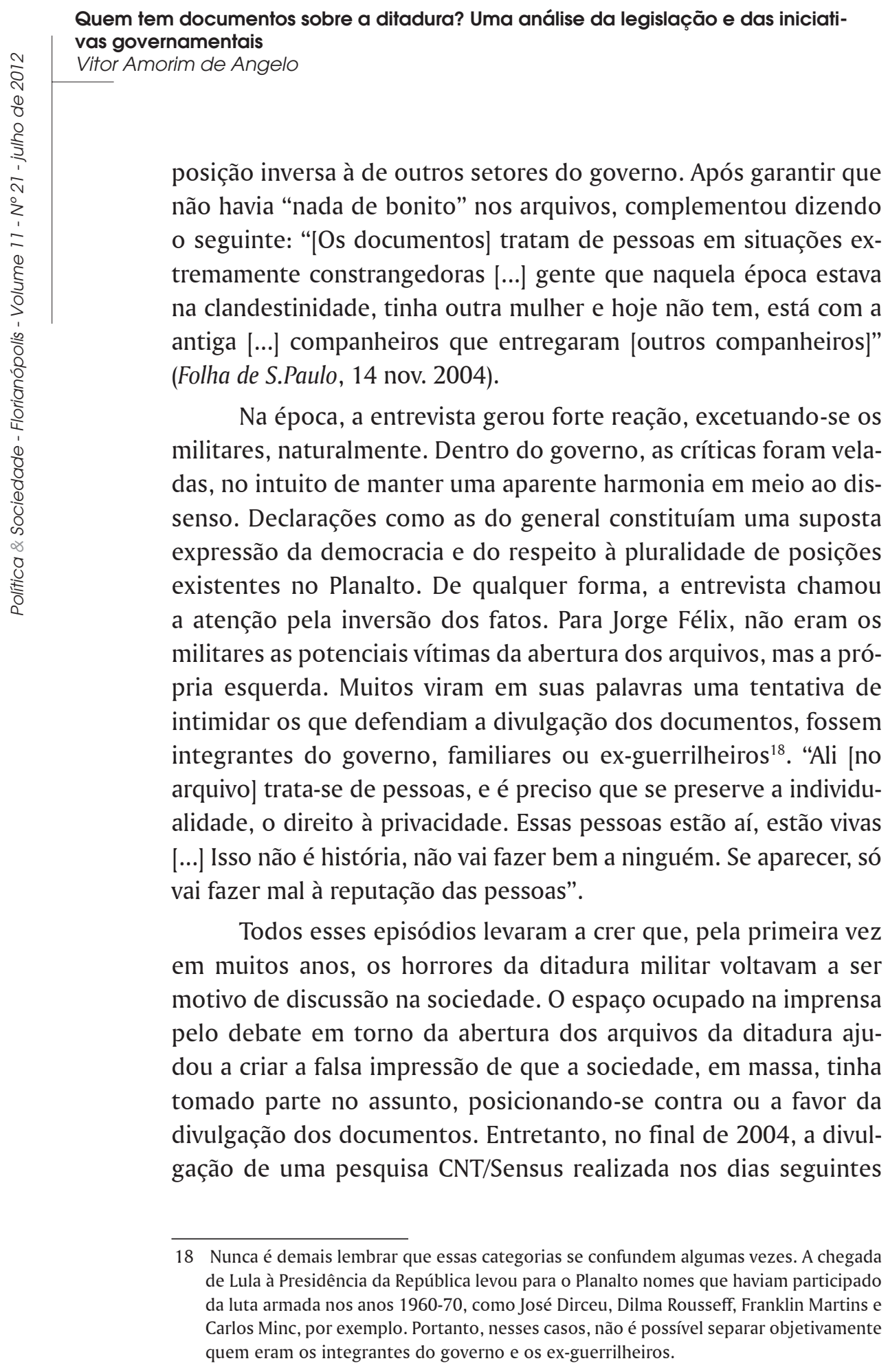


à decisão do TRF informou que 73,3\% dos entrevistados simplesmente desconheciam ou não acompanhavam a discussão (O Globo, 15 dez. 2009). Numa espécie de reedição do que havia sido a luta armada no Brasil, ficou claro que tudo estava ocorrendo à revelia da maioria da sociedade (RIDENTI, 1993).

$\mathrm{O}$ acerto de contas com nosso passado recente, do qual a abertura dos arquivos é apenas uma - e não por isso menos importante — das questões em jogo, tem se mantido num estado de pleno divórcio com o conjunto da sociedade ${ }^{19}$. Nesse ponto, ganha relevo a questão dos desaparecidos políticos, pois, como Maia (2009, p. 287) bem observou, "as zonas de sombra que encobrem o esclarecimento cabal dos casos de 'desaparecimento' de perseguidos políticos parecem ser o mais grave sintoma dessa estranha convivência da sociedade brasileira com informações que permanecem secretas indefinidamente". No Brasil, não se verifica, como em países vizinhos, movimentos de massa reunindo amplos setores da sociedade em defesa desta ou daquela bandeira em favor do direito à memória do período. Muito além do que a simples oposição entre memória e esquecimento, como se ambos fossem dois lados de uma mesma dinâmica, o mundo contemporâneo tem vivenciado um processo de transformação na própria memória. Levi (2001, p. 31-32) sintetiza da seguinte maneira o quadro atual:

O processo triunfal da individualização, da privatização da experiência, produziu uma memória fragmentada, individualizada. É a memória de cada um, não a de um grupo ou de um povo, que entra continuamente em cena: não mais uma história comunicável, mas uma autobiografia, não mais o passado da sociedade, mas uma miríade de fragmentos e objetos separados ${ }^{20}$.

Tomemos como exemplo o caso das reparações financeiras às vítimas de perseguição política e a seus familiares. Trata-se de uma justa iniciativa - e que integra o rol de ações possíveis da chamada justiça de transição — do governo brasileiro no sentido de

19 Para uma análise a esse respeito, ver Gagnebin (2010).

20 Tradução livre do original em francês. 


\section{Quem tem documentos sobre a ditadura? Uma análise da legislação e das iniciati- vas governamentais \\ Vitor Amorim de Angelo}

atenuar materialmente as perdas também materiais sofridas pelas vítimas da ditadura e de, simbolicamente, reconhecer as consequências danosas da ação do Estado naquele período. Contudo, ao se converter na principal iniciativa dos sucessivos governos da Nova República (MEZAROBBA, 2007), a reparação financeira individualizou a política de memória, reforçando um quadro já fragmentado, em nada contribuindo, portanto, para um efetivo encontro da sociedade com seu próprio passado.

\section{Os avanços na divulgação de documentos sigilosos}

Em novembro de 2005, seis meses após a promulgação da lei n. 11.111, um novo decreto assinado pelo presidente Lula determinou a imediata transferência para o Arquivo Nacional dos documentos produzidos ou recebidos pelo Conselho de Segurança Nacional (CSN), pela Comissão Geral de Investigações (CGI) e pelo Serviço Nacional de Informações (SNI) - todos sob custódia da Agência Brasileira de Informação (Abin). O decreto atribuiu novas competências para a então ministra-chefe da Casa Civil, Dilma Rousseff, a propósito do recolhimento e divulgação dos arquivos, dispondo também sobre a criação de um grupo supervisor formado por representantes da Casa Civil, do Gabinete de Segurança Institucional e da Secretaria-Geral da Presidência da República, além de integrantes do ministério da Defesa, da Justiça e da AGU (Decreto n. 5.584/2005).

O decreto reforçou um dos aspectos mais evidentes nas constantes mudanças no primeiro escalão do governo: o gradativo afastamento da Secretaria Especial de Direitos Humanos das discussões visando à abertura dos arquivos da ditadura. Embora tivesse status diferenciado, com lugar garantido nas reuniões ministeriais, a SEDH foi deixada de lado num assunto que, na visão de muitos, relacionava-se diretamente com suas atribuições. Durante o governo Lula, foram a Casa Civil e o ministério da Defesa os dois órgãos emergentes em termos de novas atribuições e poderes no 
que dizia respeito ao tema. O ministério da Justiça, por sua vez, manteve uma parte do espaço que possuía desde o governo FHC.

Até aquele momento, nem a Casa Civil nem a pasta da Defesa tinham sido ocupadas por nomes abertamente hostis à proposta de abertura dos arquivos. Como se sabe, o primeiro titular daquele ministério no governo Lula foi José Dirceu, conhecido líder estudantil na época da ditadura. Em 1969, Dirceu foi banido para o México após ser trocado com outros companheiros pelo embaixador norte-americano Charles Burke Elbrick, sequestrado no Rio de Janeiro por militantes do Movimento Revolucionário 8 de outubro (MR-8) e da Ação Libertadora Nacional (ALN). Em 2005, em meio à crise do mensalão, foi substituído por Dilma Rousseff, que nos anos 1970 militara na Vanguarda Popular Revolucionária (VPR), um dos principais grupos da esquerda armada brasileira. No caso do ministério da Justiça, a situação também não era diferente. Seu titular à época, Márcio Thomaz Bastos, sempre se declarou favorável à divulgação dos documentos.

O trabalho de recolhimento e organização dos arquivos consumiu três anos até que o Arquivo Nacional, subordinado à Casa Civil, disponibilizasse em seu sítio na internet parte dos documentos recolhidos na Abin. Durante esse período, à exceção das atividades da CEMDP, o fato mais relevante a ser registrado foi o lançamento do livro Direito à verdade e à memória, editado pela Secretaria Especial dos Direitos Humanos, cujo titular, na época, era Paulo Vannuchi - ele também um ex-integrante da esquerda armada. Na prática, o livro constitui um verdadeiro relatório do trabalho realizado pela Comissão Especial sobre Mortos e Desaparecidos até 2006. Nele está disponível uma detalhada reconstrução histórica da ditadura militar no Brasil e da trajetória da CEMDP, além de fichas com os dados do processo de cada desaparecido político.

A publicação de Direito à verdade e à memória teve vários significados. Pela primeira vez, desde o fim da ditadura militar, o Estado brasileiro reconhecia oficialmente a violação dos direitos humanos por parte de agentes das forças de segurança. Até então, todas as manifestações e documentos públicos tinham apontado 


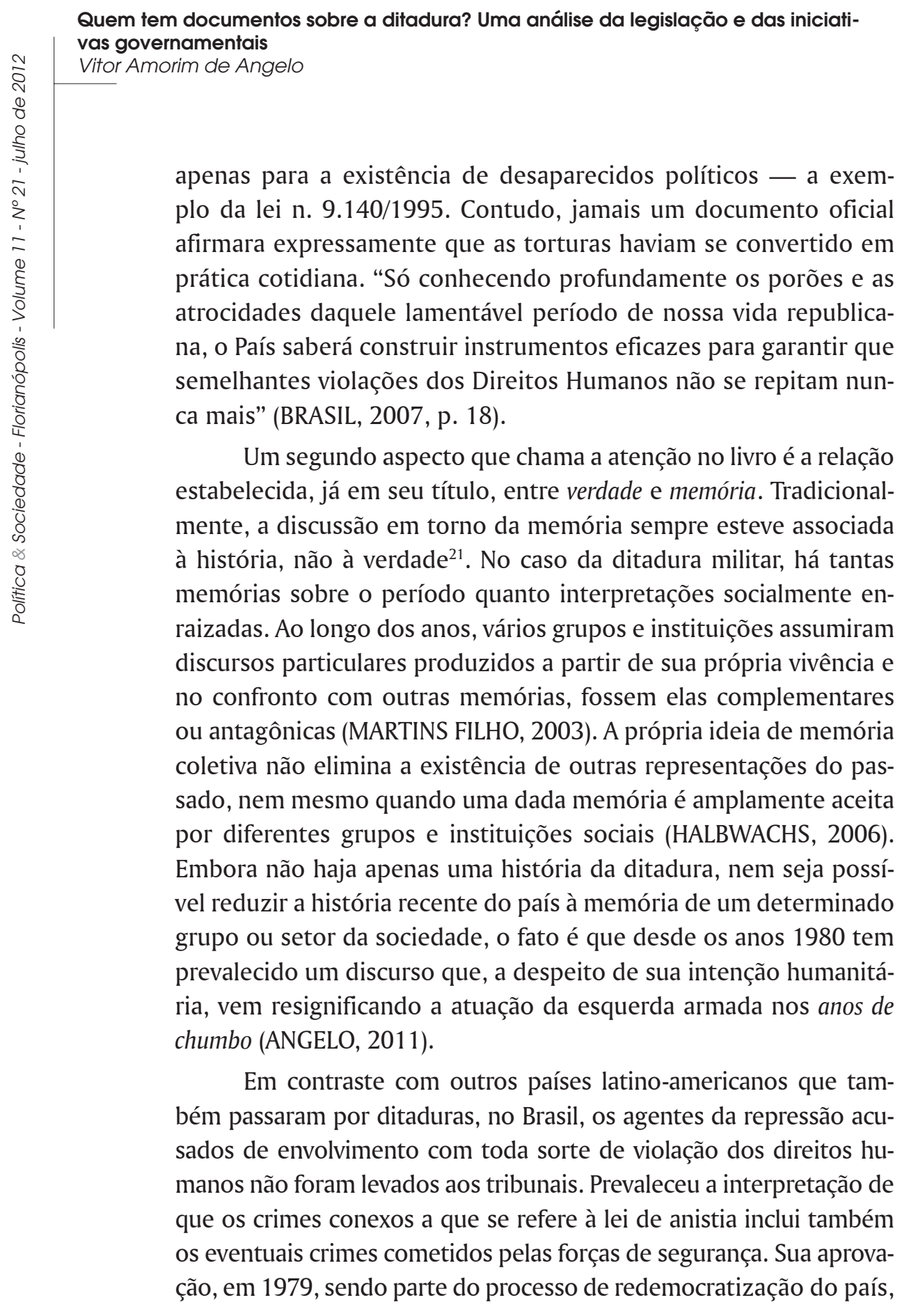

21 Para um resumo das posições a respeito da verdade em história, ver Reis (2006, p. 147-177). 
teria exigido, por esse ângulo, o esquecimento, o perdão mútuo - o sentido próprio das anistias ${ }^{22}$. No caso brasileiro, entretanto, parece ter havido aquilo que Paul Ricœur chamou de excesso de esquecimento (RICEEUR, 2007). A reconciliação da sociedade brasileira se deu à custa da impossibilidade das diferentes memórias se manifestarem naquele momento ${ }^{23}$.

Com as competências que lhe haviam sido conferidas pelo decreto n. 5.584, a ministra Dilma Rousseff anunciou, em dezembro de 2005, a transferência de todos os documentos em poder da Abin para o Arquivo Nacional. Na ocasião, a ministra ressaltou que, "ao tirar os arquivos dos órgãos de inteligência e passar para órgãos arquivísticos, se permite preservar a memória do país e que a sociedade reflita sobre os valores da democracia" (BRASIL, 2007, p. 44). Os documentos encaminhados ao Arquivo Nacional totalizaram 13 arquivos de aço contendo fotos, cartazes, filmes, livros, panfletos e revistas, além de milhares de microfichas e aproximadamente 1.200 caixas-arquivo.

Em tese, tudo o que havia sido produzido até 1975 estaria disponível para consulta, tendo em vista que a classificação mais alta - ultrassecreta, com prazo de 30 anos - expirava justamente em 2005. As exceções ficariam por conta dos documentos que possuíssem "informações relacionadas à intimidade, vida privada, honra e imagem de pessoas" (Lei n. 11.111/2005) e dos que tivessem seu sigilo renovado pela CAAIS a fim de garantir a "a segurança da sociedade e do Estado" (Decreto n. 5.301/2004). Assim, dada

22 Recentemente, em resposta ao questionamento feito pela OAB, o STF decidiu manter a interpretação de uma anistia de parte a parte. Sobre a decisão do STF, ver Folha de S.Paulo, 30 abr. 2010. Para sua repercussão no governo, nas Forças Armadas e na sociedade, ver edições de 01, 02, 04 e 05/05/2010. Poucas semanas após a sessão do STF, pesquisa do Datafolha indicou que $45 \%$ dos brasileiros eram contrários à condenação de agentes do aparelho repressivo da ditadura, enquanto $40 \%$ se declaravam a favor da proposta (Folha de S.Paulo, 7 jun. 2010).

23 Nesse sentido, a ideia de que os militares perderam a batalha pela memória do período é uma meia verdade. A decisão do STF, por exemplo, ao confirmar que a anistia representou uma medida conciliatória, endossou a versão militar segundo a qual ela teria sido resultado de um amplo debate (LEMOS, 2002). Para um contraponto a essa interpretação, evidenciando a possibilidade - ainda que restrita - de intervenção da oposição no debate sobre a anistia, ver Fico (s.d.). 


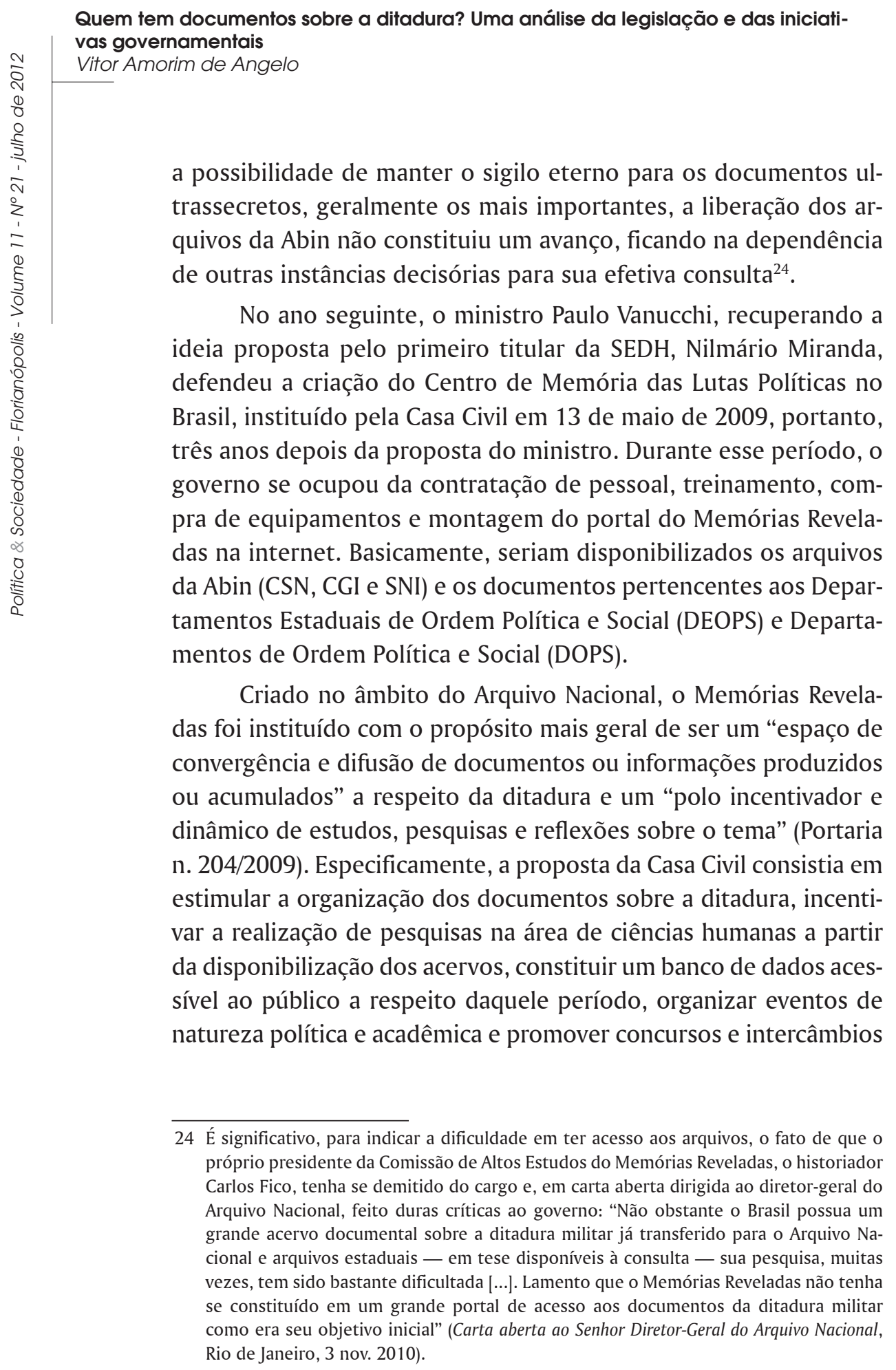


acadêmicos. Pode-se dizer que, passados quase três anos desde a sua criação, o Memórias Reveladas atendeu à boa parte dos objetivos, apesar das contradições que cercaram todo esse processo.

Afirmei anteriormente que a Casa Civil e os ministérios da Defesa e da Justiça não tinham sido ocupados por nomes abertamente hostis à abertura dos arquivos, o que facilitou os avanços obtidos no governo Lula. Durante o período de organização do acervo liberado, porém, os titulares das pastas da Defesa e da Justiça deixaram o governo. Em março de 2007, Tarso Genro, militante histórico do PT, assumiu a Justiça no lugar de Thomaz Bastos. Quatro meses depois, Waldir Pires, que sucedera José de Alencar na Defesa, desgastado com os episódios conhecidos como caos aéreo, foi substituído por Nelson Jobim, ex-presidente do STF e ministro da Justiça no governo FHC.

Tarso Genro, assim como os setores mais à esquerda dentro do governo, continuou a defender a abertura dos arquivos, de modo que sua chegada não representou nenhuma inflexão no ministério da Justiça. Jobim, entretanto, em que pesem suas declarações públicas, desde então se mostrou reativo à proposta, talvez como estratégia política para ampliar sua base de apoio dentro das Forças $\mathrm{Ar}$ madas. Ao incorporar o discurso militar segundo o qual os arquivos não poderiam ser liberados porque haviam sido destruídos, Jobim ajudou a realimentar as divisões dentro do governo ${ }^{25}$.

Em maio de 2009, por exemplo, a pasta da Defesa criou uma comissão de trabalho responsável por procurar, recolher e identificar corpos (ou restos mortais) de ex-guerrilheiros no Araguaia. A comissão, que coordenou as expedições realizadas no segundo semestre daquele ano, não contou com a participação nem do ministério da Justiça nem da SEDH, cujos titulares divergiam de Jobim, motivando, inclusive, uma nota de protesto da Comissão Especial

25 Note-se que Jobim seguiu defendendo essa tese até poucos dias antes de sua demissão do cargo, em 4 de agosto de 2011. Segundo ele: "Não há documentos (sobre o governo militar). Nós já levantamos e não têm. Os documentos já desapareceram, foram consumidos à época, então não há problema nenhum em relação a essa questão" $(O$ Estado de S. Paulo, 27 jun. 2011). 


\section{Quem tem documentos sobre a ditadura? Uma análise da legislação e das iniciati- vas governamentais \\ Vitor Amorim de Angelo}

sobre Mortos e Desaparecidos Políticos, que se disse "constrangida” com a situação (Folha de S.Paulo, 23 jun. 2009). Os trabalhos da comissão também foram duramente criticados pela participação do Exército nas expedições e pelo fato de ocorrer sem o prévio depoimento de militares que pudessem auxiliar na localização dos corpos.

Na mesma época, um oficial do Exército que participara do combate à guerrilha, Sebastião Curió, concedeu uma importante entrevista em que relatava, com base em documentos que possuía, detalhes sobre a terceira expedição militar na região ( 0 Estado de S. Paulo, 20 jun. 2009). A reportagem teve grande repercussão e revelou que existiam, sim, ao contrário do que afirmavam as Forças Armadas e o ministro da Defesa, documentos a respeito da repressão durante a ditadura ${ }^{26}$. 0 esvaziamento do discurso militar já ocorria desde o final de 2004, quando o programa Fantástico, da Rede Globo, exibiu uma reportagem mostrando que documentos secretos do período militar tinham sido queimados ilegalmente na Base Aérea de Salvador. Em 2007, o tenente José Vargas Jiménez chegou a publicar um livro com documentos secretos, jamais disponibilizados à sociedade, a fim de subsidiar o Exército na concessão de honraria por sua participação no combate à guerrilha do Araguaia (JIMÉNEZ, 2007).

\section{A campanha publicitária do Memórias Reveladas}

Foi dentro desse contexto que o Centro de Referência das Lutas Políticas no Brasil lançou sua campanha na mídia rádio-televisiva e impressa. A primeira observação que se pode fazer a respeito da campanha publicitária foi sua extrema qualidade. Veiculada nacionalmente nas principais emissoras de rádio televisão, além de jornais e revistas, a iniciativa teve um custo aproximado de R\$ 13 milhões, graças a um expressivo desconto para campanhas de

26 Rolland (2008), por exemplo, traz evidências sobre a existência de documentos da ditadura ao discutir seu uso em sítios de contra-memória na internet mantidos por ex-militares. 
utilidade pública. A preparação das peças impressas foi confiada à agência Matisse, vencedora da concorrência realizada pelo governo federal, enquanto na televisão os spots publicitários foram assinados pelos cineastas Cao Hamburguer, Helvécio Ratton e João Batista de Andrade.

Para a televisão, os produtores adotaram como estratégia o apelo sentimental, no intuito de comover o público com as histórias apresentadas. Não houve, assim, nenhuma tentativa de oferecer uma versão crítica dos episódios relatados nem tampouco de confrontar a memória dos atingidos pela repressão à versão oficial dos fatos. Num dos filmes, a mãe de um desaparecido político declama um verso enquanto a câmera corre pela casa até focalizar o quadro afixado na parede, onde está uma foto em preto e branco de seu filho. "Hei de vê-lo voltar, o meu doce consolo, o meu filhinho. Passam-se anos, e o véu do esquecimento baixando sobre as coisas tudo apaga. Menos da mãe, no triste isolamento, a saúde que o coração lhe esmaga", ela diz².

"Ele deve ter morrido na tortura dois dias depois. Eu reencontrei minha mãe treze dias depois [...] Ela não conseguia nem andar direito, de tão magra que ela estava. E aí começamos a chorar os dois".

"Eu sei que ela está morta. Eu sei. As circunstâncias nós não sabemos até hoje. É um vazio".

"Eu, quando falo, parece que estou vendo aqueles dias tão tristes da minha vida. Eu acho que uma mãe nunca esquece um filho"28.

A campanha televisiva tradicionalmente se diferencia das propostas para o rádio e a mídia impressa pela possibilidade de

27 As peças publicitárias veiculadas na mídia estão disponíveis em: www.memoriasreveladas.gov.br. Acesso em: 1 ago. 2010.

28 Respectivamente, declaração de Marcelo Rubens Paiva, filho do ex-deputado Rubens Paiva; Diva Santana, irmã de Dinaelza Santana Coqueiro, desaparecida na guerrilha do Araguaia juntamente com seu marido, Vandick Coqueiro - ambos militantes do PCdoB; e Elzita de Santa Cruz Oliveira, mãe de Fernando de Santa Cruz Oliveira, militante da Ação Popular-Marxista-Leninista (AP-ML). Grifos meus. 


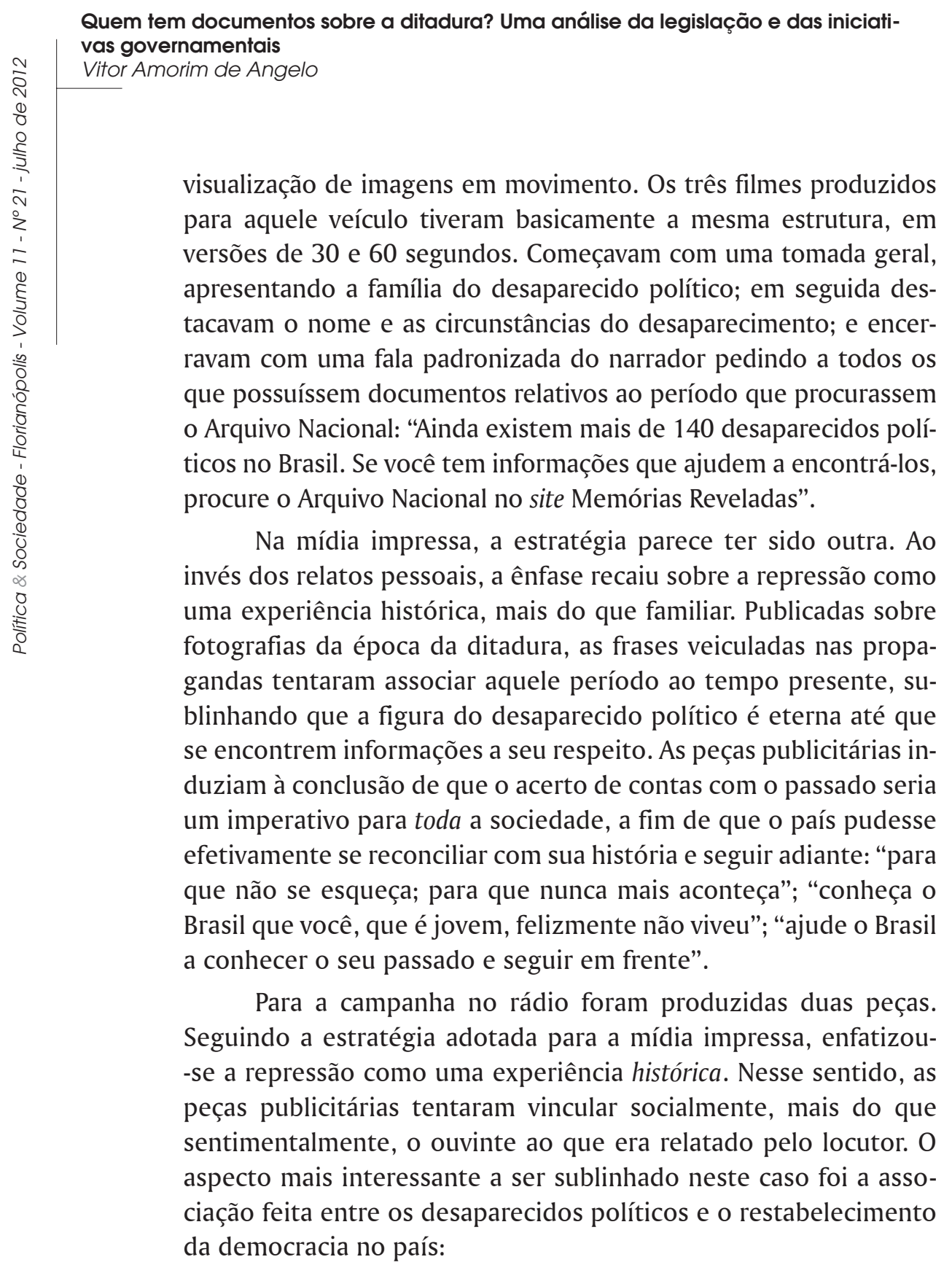

"A região do Araguaia já foi palco de um conflito armado onde brasileiros sonharam, lutaram e morreram por um Brasil mais justo. Hoje a democracia está consolidada em nosso país. Mas temos uma dívida com as famílias dos desaparecidos políticos desse confronto. Elas têm o direito sagrado de enterrar os corpos de seus entes queridos". 
"O Brasil viveu mais de vinte anos de regime de exceção, época em que até a democracia era um sonho. E sonhar era proibido. Felizmente, esse tempo acabou, mas ainda existem mais de 140 desaparecidos políticos no país"29.

Como já foi dito, a maioria dos desaparecidos políticos brasileiros é composta por militantes de esquerda que pegaram em armas para derrubar a ditadura. Parte deles tombou na região do Araguaia, onde foi travado o único confronto efetivo entre a ditadura e as organizações armadas. A ideia segundo a qual seus integrantes lutavam pela democracia, como se depreende das citações anteriores, consolidou-se ao longo do processo de abertura, quando, numa engenhosa reconstrução histórica, ocorreram certos “deslocamentos de sentido" (REIS FILHO, 2000, p. 70).

No caso da luta armada, um exemplo de releitura do passado foi atribuir àquelas organizações o apego à democracia suplantada pelo golpe civil-militar de 1964 . Deve-se recordar que a democracia era vista como um regime burguês e, nesse sentido, uma engodo liberal. A democracia pré-1964 era percebida como "sinônimo de acordos, negociatas, conchavos" (ARAÚJO, 2007, p. 328), além de estar associada à estratégia nacional-democrática do PCB, contra a qual a esquerda armada se posicionou. No lugar da democracia burguesa, propunha-se a democracia socialista; em vez da ditadura de uma minoria, a ditadura do proletariado. Tudo isso através da revolução, não de reformas. Por isso, ao se apagar o caráter ofensivo que sempre marcou a esquerda armada, bem como suas reais intenções, esta passou a ser vista como uma espécie de braço armado da sociedade em luta contra a ditadura $e$ na defesa da democracia.

Em todos os textos produzidos por aquelas organizações, a democracia burguesa, tal como a conhecíamos até 1964, era abertamente desprezada ${ }^{30}$. A derrubada da ditadura tinha um caráter fundamentalmente tático para a esquerda armada, uma vez que,

29 Grifos meus.

30 Alguns textos estão disponíveis em Reis Filho e Sá (2006). 


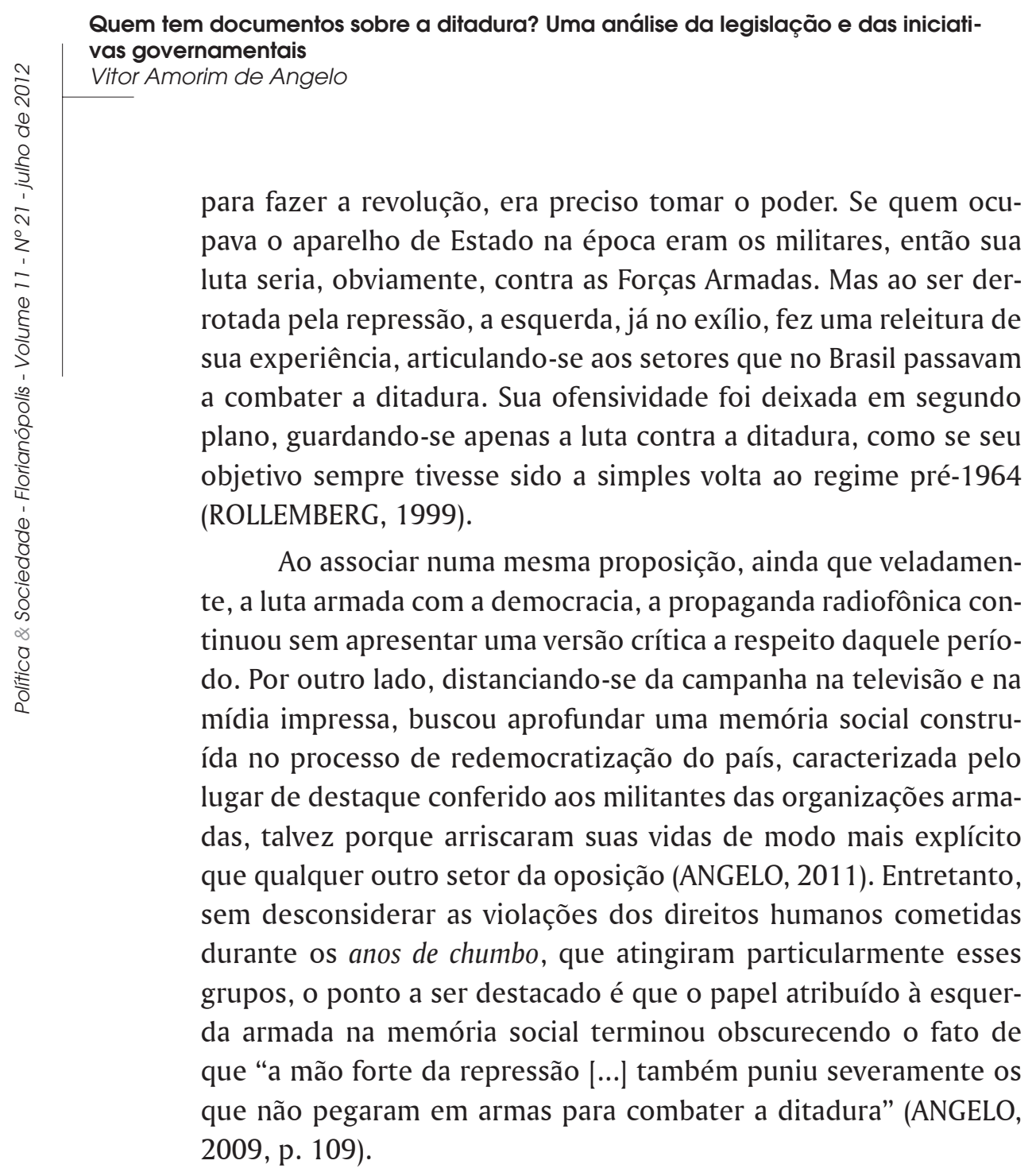

\section{Considerações finais}

Em setembro de 2009, na mesma época em que era lançada a campanha publicitária do Memórias Reveladas, o então ministro Paulo Vannuchi declarou, em entrevista, que independente de qualquer "divergência ideológica, histórica ou política sobre o período, ninguém pode ter divergência sobre o direito de localizar os restos mortais e sepultar" (Folha de S.Paulo, 26 set. 2009). Mesmo 
sem ser publicada, não é muito difícil imaginar qual tenha sido a pergunta do repórter. Naquele contexto que antecedia à campanha, talvez algo como: o senhor acredita que militares atenderão ao chamado do governo, entregando documentos que ajudem a encontrar desaparecidos políticos?

É amplamente conhecido que houve profundas divergências históricas, políticas e ideológicas entre os militares e aqueles que pegaram em armas para derrubar a ditadura, que constituem a maior parte dos desaparecidos políticos do Brasil, como já foi destacado. Em Direito à memória e à verdade basta consultar as fichas biográficas dos atingidos pela repressão para concluir que quase todos estavam ligados a alguma sigla da esquerda armada. Contudo, o que nos faria acreditar que os envolvidos em todo o tipo de violação dos direitos humanos concordariam, de boa-fé, tornar públicas informações que, a despeito de facilitarem as investigações sobre os desaparecidos políticos, poderiam, ao mesmo tempo, comprometê-los judicialmente? ${ }^{31}$.

Além do mais, não é essa atitude voluntarista em que acredita o ex-ministro que vem caracterizando, até aqui, o comportamento dos militares que fizeram parte do aparelho repressivo durante a ditadura ou mesmo que, por simples ofício, mantêm ligações com as Forças Armadas. Todas as suas declarações, na verdade, têm caminhado no sentido oposto à colaboração com a Comissão Especial de Mortos e Desaparecidos Políticos instituída em 1995 no governo FHC para coordenar os trabalhos de investigação e reparação dos perseguidos políticos da ditadura militar ${ }^{32}$. Como

31 Mesmo com a recente decisão do STF a propósito da anistia, algumas famílias têm buscado responsabilizar os agentes da repressão ao menos na esfera civil, de modo que o perdão de 1979 não constitui sequer um fator de incentivo para os militares que eventualmente possuam documentos sobre a ditadura os encaminhem ao Arquivo Nacional.

32 Ainda na primeira semana do governo Dilma Rousseff, por exemplo, o novo chefe do Gabinete de Segurança Institucional da Presidência da República, general José Elito Siqueira, declarou em entrevista que os desaparecidos políticos durante a ditadura devem ser vistos como "fato histórico", e não como motivo de vergonha para o país: "Nós temos que ver o 31 de março de 1964 como dado histórico de nação, seja com prós e contras, mas como dado histórico de nação. Da mesma forma, os desaparecidos são história da nação, que nós não temos que nos envergonhar ou nos vangloriar. Nós 


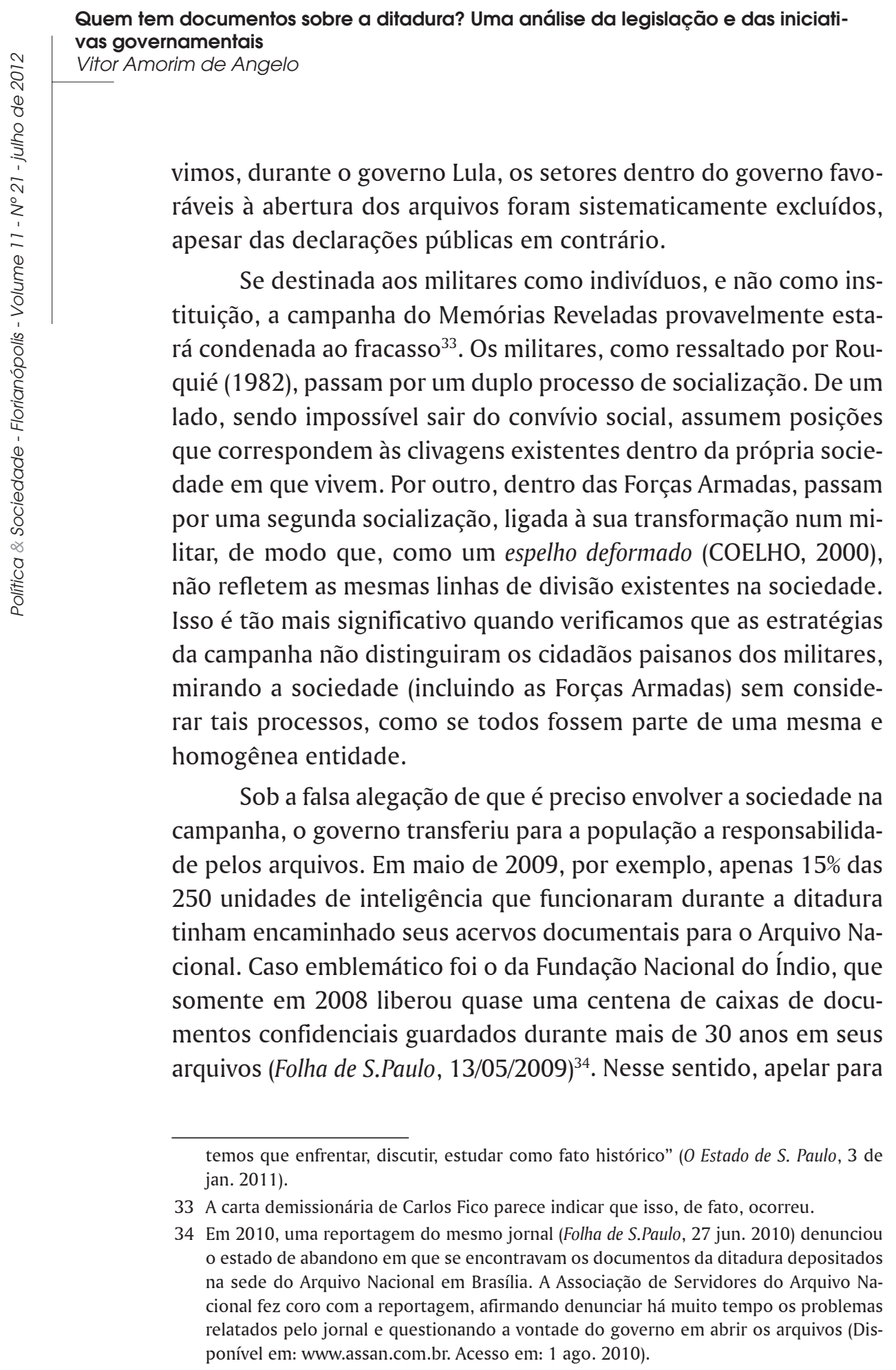


que a sociedade - incluindo os militares - entregue algum documento a respeito daquele período, quando se sabe que o próprio Estado, que foi o maior produtor dessas informações, ainda guarda boa parte do acervo, parece ser, no mínimo, contraditório.

Para o público externo, todavia, permanecem as contundentes declarações que buscam ressaltar a firme disposição do governo brasileiro em abrir os arquivos da ditadura, a exemplo do que afirmou o ministro Vanucchi uma semana depois da entrevista de Curió "O presidente Lula anunciou o site Memórias Reveladas, que é a abertura ampla de todos os arquivos à disposição, e uma portaria interministerial determinando o recolhimento de todo e qualquer arquivo, como este do Curió [...], que esteja indevidamente retido em mãos privadas" (Folha de S.Paulo, 27/06/2009. Grifos meus). Porém, nem o presidente tinha poderes para determinar tal coisa nem tampouco a portaria a que se referiu o ministro possuía o conteúdo indicado, determinando, na verdade, "a realização de chamada pública para entrega de documentos e registro de informações referentes ao período de $1^{\circ}$ de abril de 1964 a 15 de março de 1985" (Portaria interministerial n. 205/2009) ${ }^{35}$.

Portanto, qual o sentido da campanha do Memórias Reveladas? A iniciativa parece ter sido mais uma resposta à pressão internacional para que o país tomasse medidas efetivas nesse sentido. É significativo que em maio de 2009 o governo tenha encaminhado ao Congresso Nacional um projeto de lei que, revogando a lei $\mathrm{n}$. 11.111, aprovada no próprio governo Lula, estabelecia regras mais flexíveis para a divulgação e o acesso a informações sigilosas (Lei n. 5.228/2009). No mesmo mês, a despeito de suas conhecidas posições, o ministro da Defesa, como vimos, instituiu uma comissão de trabalho a fim de realizar expedições no Araguaia. Todas essas medidas, curiosamente, aconteceram na mesma época em que a Comissão Interamericana de Direitos Humanos, entidade ligada à Organização dos Estados Americanos, entrou com uma ação contra o governo brasileiro na Corte Interamericana de Direitos Hu-

35 Destaque-se ainda que o documento nem mesmo é assinado pelo presidente Lula. 


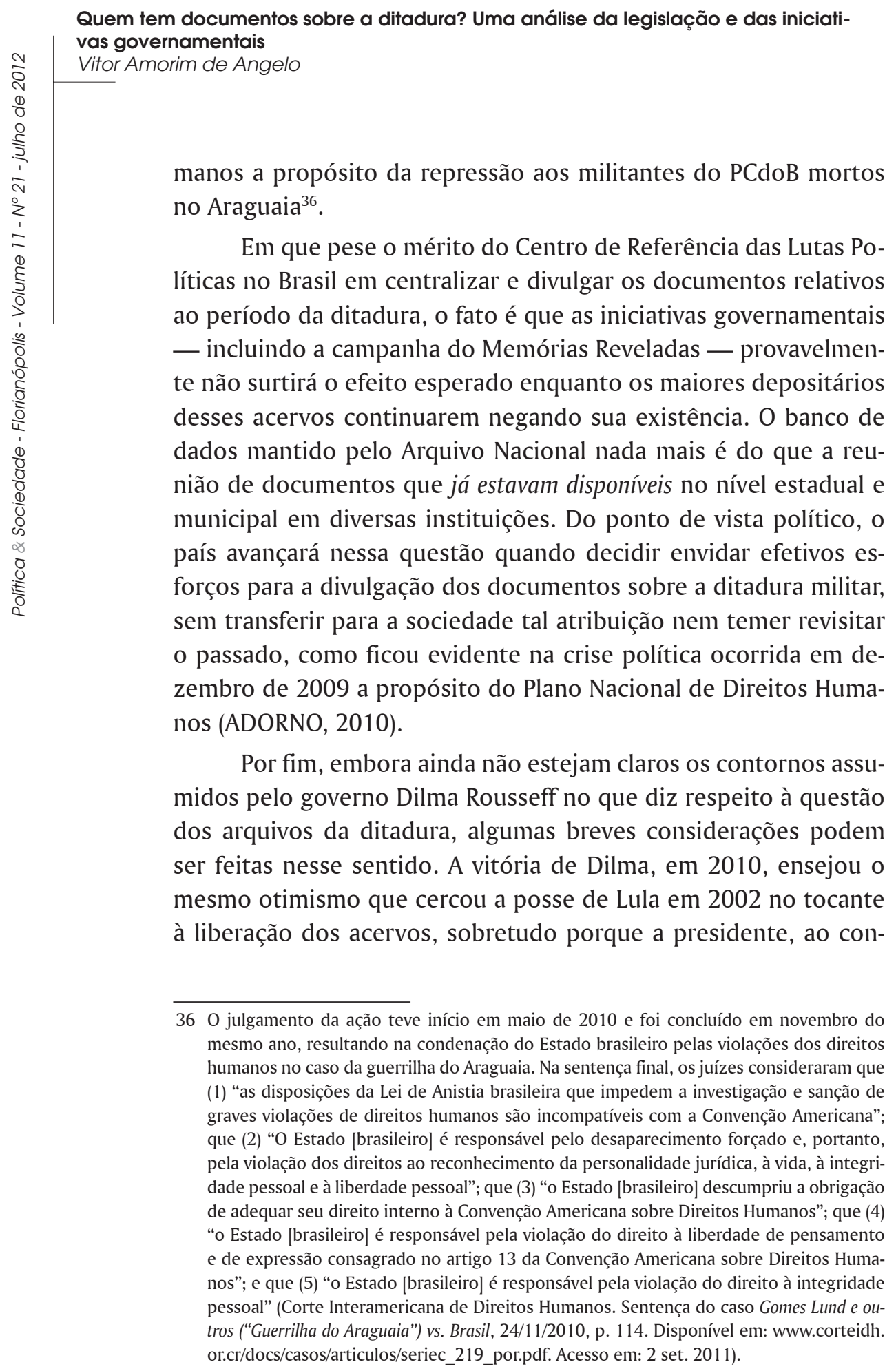


trário de seu antecessor, foi militante da esquerda armada. No início de 2011, em sugestiva reportagem intitulada Is Brazil ready to face the skeletons of its Junta years?, a revista norte-americana Time (8 fev. 2011) expressou tal otimismo ao dizer que Dilma Rousseff parecia mais preparada para enfrentar a questão dos crimes cometidos durante a ditadura e que, em seu governo, os parentes de desaparecidos políticos poderiam ter mais audiência. Em suas primeiras declarações públicas, a presidente, de fato, parecia corresponder a esse otimismo. Em abril, como resposta à sentença da Corte Interamericana de Direitos Humanos, Dilma orientou a base aliada do governo a acelerar no Senado a aprovação do projeto de lei sobre o acesso a informações públicas, já aprovado na Câmara dos Deputados, e que acabava com a figura do sigilo eterno (Folha de S.Paulo, 14 abr. 2011).

Porém, dois meses depois, em meio a divergências políticas envolvendo dois ex-presidentes da República integrantes da base aliada (José Sarney e Fernando Collor de Mello), o Planalto recuou. O vice-presidente da República, Michel Temer, concedeu declarações públicas defendendo a continuidade do sigilo eterno para documentos ultrassecretos (O Globo, 16 jun. 2011). Ao mesmo tempo, o líder do PT no Senado, Humberto Costa, que afirmara que o partido havia chegado a um acordo para aprovar a proposta original do governo, foi obrigado, face à inflexão da presidente, a declarar que os senadores petistas queriam "ouvir os argumentos do governo e, depois, discutir qual é a posição da bancada" $(O$ Globo, 15 jun. 2011). A mudança de rumo foi muito mal recebida por vários setores da sociedade, que viram no recuo seu otimismo esvair-se, tal como acontecera oito anos antes, quando o governo Lula recorreu da decisão da juíza Solange Salgado.

A princípio, não ficou evidente se a inflexão de Dilma tinha sido produto de sua personalidade e da forma como conduzia seu governo - vários críticos da presidente chamaram a atenção para o fato de que ela costuma tergiversar nas tomadas de decisão - ou se indicava, de modo mais amplo, a continuidade do mesmo modus operandi no trato do tema, com fatores políticos se sobrepondo ao 


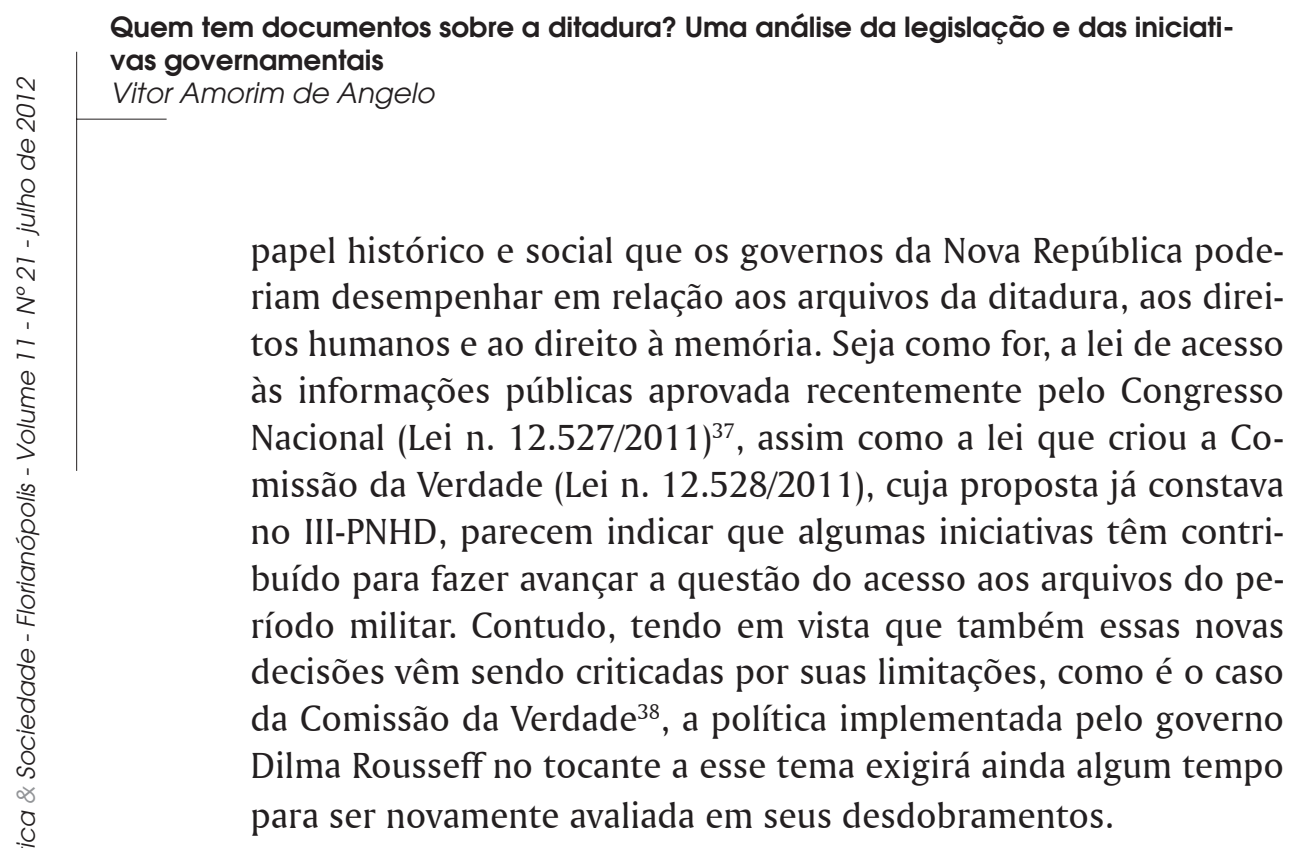

\section{Referências}

ADORNO, S. História e desventura: o 3o Programa Nacional de Direitos Humanos. Novos Estudos CEBRAP, São Paulo, n. 86, p. 5-20, mar. 2010.

37 Em comparação com as medidas aprovadas durante o governo Lula (Decreto n. 5.301/2004 e Lei n. 11.111/2005), a lei de acesso a informações públicas sancionada pela presidente Dilma em de novembro de 2011 definiu apenas três tipos de classificação de dados e documentos oficiais: reservados, secretos e ultrassecretos. Respectivamente, o prazo para liberação das informações foi fixado em 5, 15 e 25 anos. Portanto, diminui-se o número de classificações bem como o prazo para o acesso às informações públicas na comparação com o governo anterior. Além disso, foi instituída uma Comissão Mista de Reavaliação de Informações com poderes para prorrogar uma única vez o prazo para acesso aos dados e documentos classificados como ultrassecretos. Em todos os casos, os dados e documentos que digam respeito à violação dos direitos humanos não poderão sofrer nenhum tipo de restrição de acesso.

38 Embora a Comissão da Verdade não diga respeito aos arquivos da ditadura em si, sua instituição representa uma espécie de face complementar daquela iniciativa — não por outro motivo, as duas leis foram sancionadas pela presidente Dilma na mesma data. As críticas à Comissão têm destacado (1) sua falta de autonomia financeira, (2) sua subordinação político-institucional ao ministério da Casa Civil da Presidência da República, (3) seu reduzido número de membros (sete no total, além de 14 cargos de assessoramento), (4) o prazo exíguo, apenas dois anos, para examinar as violações dos direitos humanos cometidas no período previsto em lei e (5) a ampliação desse período histórico para além da ditadura militar, cobrindo os anos de 1946 a 1988. 
ANGELO, V. A. de. Luta armada no Brasil. São Paulo: Claridade, 2009.

. Ditadura militar, esquerda armada e memória social no Brasil. Tese (Doutorado em Ciências Sociais) - Universidade Federal de São Carlos, 2011.

ARAÚJO, M. P. N. Lutas democráticas contra a ditadura. In: REIS FILHO, D. A.; FERREIRA, J. (Orgs.). Revoluções e democracia (1964...). Rio de Janeiro: Civilização Brasileira, 2007. p. 323-353.

BLOCH, M. Apologia da história ou o ofício do historiador. Rio de Janeiro: Jorge Zahar, 2001.

BRASIL. Secretaria Especial dos Direitos Humanos. Comissão Especial sobre Mortos e Desaparecidos políticos. Direito à verdade e à memória. Brasília: Secretaria Especial dos Direitos Humanos, 2007.

COELHO, E. C. Em busca de identidade: o Exército e a política na sociedade brasileira. Rio de Janeiro: Record, 2000.

COMISSÃO Interministerial. Relatório da Comissão Interministerial criada pelo decreto n. 4.850/2003, com vistas à identificação de desaparecidos na Guerrilha do Araguaia. Texto não publicado, 2007.

FICO, C. A negociação parlamentar da Anistia de 1979 e o chamado "perdão aos torturadores". Texto não publicado. Disponível em: <www.ppghis.ifcs.ufrj.br>. Acesso em: 18 ago. 2010.

GAGNEBIN, J. M. O preço de uma reconciliação extorquida. In: TELES, E.; SAFATLE, V. (Orgs.) O que resta da ditadura. São Paulo: Boitempo, 2010. p. 177-186.

GASPARI, E. A ditadura encurralada. São Paulo: Companhia das Letras, 2004.

GORENDER, J. Combate nas trevas: a esquerda armada - das ilusões perdidas à luta armada. 2. ed. São Paulo: Ática, 1987. 
Quem tem documentos sobre a ditadura? Uma análise da legislação e das iniciativas governamentais

Vitor Amorim de Angelo

HALBWACHS, M. A memória coletiva. 2. ed. São Paulo: Centauro, 2006.

HEYMANN, L. O "devoir de mémoire" na França contemporânea: entre a memória, história, legislação e direitos. In: GOMES, Â. de C. (Org.). Direitos e cidadania: memória, política e cultura. Rio de Janeiro: FGV, 2007, p. 15-43.

JIMÉNEZ, J. V. Bacaba: memórias de um guerreiro de selva da guerrilha do Araguaia. Campo Grande: Editora do Autor, 2007.

LEMOS, R. Anistia e crise política no Brasil pós-1964. Topoi, Rio de Janeiro, p. 287-313, dez. 2002.

LEVI, G. Le passé lointain: sur l'usage politique de l'histoire. In: HARTOG, F.; REVEL, J. (Dirs.) Les usages politiques du passé. Paris: Éditions de l'EHESS, 2001. p. 25-38.

MAIA, M. A arte de manter em segredo atos praticados por agentes públicos. In: SANTOS, C. M. et al. (Orgs.) Desarquivando a ditadura: memória e justiça no Brasil. v. 1. São Paulo: Hucitec, 2009, p. 287-311.

MARTINS FILHO, J. R. A guerra da memória: a ditadura militar nos depoimentos de militares e militantes. Varia História, Belo Horizonte, n. 28, p. 178-201, 2003.

MEZAROBBA, G. 0 preço do esquecimento: as reparações pagas às vítimas do regime militar (uma comparação entre Brasil, Argentina e Chile). Tese (Doutorado em Ciência Política) - Universidade de São Paulo, 2007.

MIRANDA, N.; TIBÚRCIO, C. Dos filhos deste solo: mortos e desaparecidos políticos durante a ditadura militar - a responsabilidade do Estado. São Paulo: Fundação Perseu Abramo, 1999.

MORAIS, T.; SILVAM, E. Operação Araguaia: os arquivos secretos da guerrilha. São Paulo: Geração Editorial, 2005. 
NOGUEIRA JÚNIOR, A. Cidadania e controle democrático do acesso aos documentos sigilosos. Palestra proferida em 7 abr. 2004. Disponível em: <www.cpdoc.fgv.br> . Acesso em: 18 ago. 2010.

REIS, J. C. História \& Teoria: historicismo, modernidade, temporalidade e verdade. 3. ed. Rio de Janeiro: FGV, 2006.

REIS FILHO, D. A. Ditadura militar, esquerdas e sociedade. Rio de Janeiro: Jorge Zahar, 2000.

REIS FILHO, D. A.; SÁ, J. F. de (Orgs.). Imagens da revolução: documentos políticos das organizações clandestinas de esquerda dos anos 1961-1971. 2. ed. São Paulo: Expressão Popular, 2006.

RICEUUR, P. A memória, a história, o esquecimento. Campinas: Unicamp, 2007.

RIDENTI, M. O fantasma da revolução brasileira. São Paulo: Unesp, 1993.

ROLLAND, Denis. Linstrumentalisation du passé: mémoire vive incertaine, révisionnisme et délation sur internet. In: SANTOS, Idelette Muzart Fonseca dos; ROLLAND, Denis (Orgs.) Le Brésil des gouvernements militaires et l'exil. Paris: L'Harmattan, 2008.

ROLLEMBERG, D. Exílio: entre raízes e radares. Rio de Janeiro: Civilização Brasileira, 1999.

ROUQUIÉ, A. LÉtat militaire en Amérique Latine. Paris: Seuil, 1982.

\section{Abstract}

Who has the Brazilian dictatorship's files? An analysis about the legislation and the Brazilian government initiatives

Based on the Brazilian Political Struggles Reference Center's advertising campaign, also known as Revealed Memories, our objective in this paper is to discuss the positioning of the Brazilian Government regarding to the military dictatorship archives. For this purpose, we recover the 
Quem tem documentos sobre a ditadura? Uma análise da legislação e das iniciativas governamentais

Vitor Amorim de Angelo

long debate started in the FHC rules about the divulgation of the secret documents produced by the regime. The reconstruction of this debate and the critical analysis of the advertising campaign has allowed us to demonstrate the limits and contradictions of Brazilian Government's performance on this issue.

Keywords: Dictatorship. Documents. Advertising campaign. 